\title{
Small and Thriving: A Follow-Up to "The Future of the Small Theological Library"
}

Susan Ebertz, Wartburg Theological Seminary Elizabeth Young Miller, Moravian Theological Seminary Myka Kennedy Stephens, Lancaster Theological Seminary

\begin{abstract}
Being small does not have to be a liability for theological libraries. This is the argument Myka Kennedy Stephens makes in her essay published in the April 2016 issue of Theological Librarianship. Instead, being small is something to take seriously and, in many cases, celebrate. As distance learning, hybrid pedagogy, and flipped classrooms continue to make inroads in theological education, how do we now envision the future of small theological libraries? This panel will explore and discuss habits that make theological librarians in smaller contexts successful. Staying attuned to needs, optimizing resources, and acting boldly are the habits Stephens names in her essay. This panel will discuss, expand, and share how these habits are applied in three small theological library contexts.
\end{abstract}

\section{INTRODUCTION}

Staying attuned to needs, optimizing resources, and acting boldlyMyka Kennedy Stephens highlights these three habits in her 2016 article in Theological Librarianship entitled "The Future of the Small Theological Library" as a means to generate conversation. ${ }^{1}$ Her article stems from her attendance at the 2014 ATS/Atla event "The Future of Libraries in Theological Education: A Conversation with Chief Academic Officers, Information Technology Officers, and Library Directors." ${ }^{2}$ Having multiple voices at the table was beneficial and demonstrates the importance of collaboration. Yet there was a lack of enthusiasm from other attendees on the future 
of small institutions. ${ }^{3}$ Certainly, being small has its disadvantages, in particular when survival becomes a primary concern, putting a damper on innovation. ${ }^{4}$ However, budget constraints can be a conversation starter and a way to explore opportunities. There is, indeed, value in being small, especially when it challenges us to become trendsetters, thinking outside of the box. ${ }^{5}$

So what does "small" look like? According to Stephens, who draws upon several sources to create a broad definition, "small” means one or more of the following apply:

- There are five or fewer full-time library staff

- The annual budget is less than $\$ 500,000$

- Institutional enrollment is under 200 FTE

- The institution self-identifies as small. ${ }^{6}$

Three years after the publication of this article, we would like to further reflect on how these three habits impact the outcomes at our small theological libraries. It is a continuation of conversation and dialogue among librarians at small theological libraries about what helps us to thrive. Elizabeth Young Miller, seminary liaison librarian at Moravian Theological Seminary and Moravian College, shares how staying attuned to needs led to innovations in reference services and information literacy instruction. Susan Ebertz, library director at Wartburg Theological Seminary, shares how optimizing resources informs her strategic planning process. Myka Kennedy Stephens, seminary librarian at Lancaster Theological Seminary, shares how acting boldly has continued to place her library on the leading edge of open source library systems.

\section{STAYING ATTUNED TO NEEDS AT MORAVIAN}

Located in Bethlehem, Pennsylvania, Moravian Theological Seminary is an embedded institution, sharing resources with Moravian College, a private liberal arts institution. I serve as the seminary liaison librarian, with approximately a third of my time dedicated to the seminary community and two-thirds focused on services to undergraduates. The seminary's FTE for spring 2019 was forty-five.

Listening and visibility are crucial and taking a proactive approach always helps. Therefore, in the fall of 2015, during my 
first semester at Moravian, I paid what I have dubbed "house calls" at the seminary-meeting individually with any interested faculty members to get a pulse on library services and needs. These meetings provided meaningful context for collection development purposes and a launching pad for new services and projects. For example, I now offer office hours one hour a week in the seminary's hub-the kitchen. Students, faculty, and staff stop by to say hello, ask a question, and/or enjoy a homemade cookie.

During the house calls with faculty, I learned of the seminary's wish to expand its distance education offerings, spurring me to examine resources and services for this population. I now offer library instruction via Zoom, as well as reference appointments. Meeting with students via Zoom to discuss their research questions and projects provides flexibility to working students and me, a mom. I also began creating a series of online tutorials focused on the following:

- Accessing our resources remotely

- Using online tools for research in theology

- Special database search features, such as the Bible citation search in Atla, and how to create a folder, as well as an alert using an EBSCO database

- Searching the online library catalog

- Requesting items through interlibrary loan

- Utilizing the Atla Reciprocal Borrowing Program, etc. ${ }^{7}$

I relied on conversations with faculty and students to develop the content of these online tutorials.

More and more students live outside of Bethlehem, so I do my best to promote and expand reciprocal borrowing agreements. Moravian has direct reciprocal borrowing partnerships with other local colleges and universities, regional seminaries, and member libraries who participate in the Atla Reciprocal Borrowing Program.

In her article, Stephens emphasizes the importance of a needs assessment that not only includes current students, faculty, and staff, but accounts for alums and local clergy too. ${ }^{8}$ Being mindful of both current students and alums, who may have limited funds and varying access to physical library resources, I have done my best to promote 
free and open source tools. I significantly expanded a research guide designed specifically for clergy and alums. ${ }^{9}$ The emphasis of this guide is primarily on free resources and includes links to congregational and professional resources, e-books, statistical sources, survey tools, and copyright information. In generating this content, I again relied on conversations with stakeholders and looked at what other libraries have done. A similar research guide created by Suzanne EstelleHolmer at Yale Divinity Library proved very valuable. ${ }^{10}$ Knowing that library patrons search our online library catalog, I also collaborated with a colleague to integrate Princeton Theological Commons into our integrated library system (ILS). This collection expands our resources to include primary sources, which can sometimes be difficult to find.

Both STEP Bible and Zotero are free resources that current students and alums alike may find valuable. Like Accordance, BibleWorks, and Logos, STEP Bible is a free tool that provides access to different translations of the Bible, as well as commentaries. ${ }^{11}$ In the past, students in intro level courses relied on BibleWorks. When I learned that updates to BibleWorks would no longer be supported, I alerted faculty to STEP Bible. Faculty and students were grateful to learn about this resource. Another free tool that students love is Zotero, a bibliographic management tool that works with Word and now Google Docs to generate citations..$^{12}$ Many students struggle with citation, so Zotero is a way to simplify their research. For financial reasons, the institution does not offer an institutional subscription to RefWorks or EndNote, fee-based competitors of Zotero. The beauty of Zotero, though, is that students, especially those working on a thesis, have access to their citations after graduation.

In the fall of 2018, I offered Zotero workshops in the library at lunchtime. However, these sessions were sparsely attended. Again, recognizing that everyone has a different schedule, I was delighted to read about Rebecca Kuglitsch and Peggy Burge's approachon-demand workshops. ${ }^{13}$ If two or more students are interested in attending a Zotero workshop, they contact a librarian to request a time that is convenient for them. ${ }^{14}$ I shared this idea with several seminary faculty members and they are supportive of this tactic. I am looking forward to trying this new approach in the fall of 2019.

In her article, Stephens envisions "a future in which [small theological libraries] are true educational partners with our 
institutions," and this is certainly one of my goals. ${ }^{15} \mathrm{I}$ am always looking for ways to contribute to and enhance the seminary's curriculum and having a seat at the table during seminary faculty meetings gives me great insight. Participating in discussions surrounding curriculum revisions has allowed me to learn what gatekeeping measures are important to faculty and then map some of them to The Framework for Information Literacy for Higher Education. ${ }^{16}$ In May 2019, during a two-day seminary meeting, I joined in the conversation regarding revisions to the course Learning in Community, also known as LinC. All seminary students, regardless of degree program, are required to take this course. After listening and then sharing some observations and concerns, the entire faculty was onboard with expanding the information literacy component of this course and requiring students to take this course during their first semester of study. Beginning fall 2019, I will be meeting with the class as a whole to provide an orientation to the library and to discuss plagiarism; this is what I have done in the past. I will then be meeting in small groups with students in each degree program to highlight relevant resources and services. I am hopeful that this new approach will be beneficial for students.

Sometimes the focus of library services revolves around students; however, it is important not to overlook faculty. In addition to attending faculty meetings, informal conversations have helped me stay attuned to their needs too. The faculty are routinely examining current degree programs and the potential for new ones. This spring, two faculty members approached me and asked for my assistance with research on a degree program. I was able to help, and we presented our findings at a faculty meeting. Since I have been at Moravian, I have noticed an increase in reference questions from faculty members, as well as requests for research consultations. In addition to word of mouth, these interactions may stem from an information literacy workshop I offered for faculty members in May 2016. After reading some articles and hearing the comment from faculty members, "I always learn something new when I come to the library," I approached the dean about offering an information literacy session for faculty. To ensure that the session would be meaningful for faculty, I created a survey to gauge their knowledge of and interest in various resources and topics. The ensuing session went very well. 
I thoroughly enjoy working at a small institution, where I can wear different hats and try new things. Having an idea and being able to implement it is rewarding, as is the ability to change course if needed. At Moravian, I have been able to stay attuned to the needs of the seminary library community by doing the following: maintaining visibility, keeping open channels of communication, listening, seeking collaborative opportunities that further the goals of the institution, aiming for inclusivity, and being receptive to new ideas and approaches. While I do not have a crystal ball to foretell the future, I believe that these habits can help small libraries remain relevant.

\section{OPTIMIZING LIBRARY RESOURCES AT WARTBURG}

Context is important in understanding my perspective in talking about optimizing library resources. About two-thirds of Wartburg Theological Seminary students are online. My focus right now is on providing comparable resources for our online students. At the same time, I need to make sure that our residential students receive the resources they need. In looking at optimizing library resources, there are four types of resources to consider: personnel resources, financial resources, physical resources, and informational resources.

Personnel resources may include paid permanent staff, student workers, and volunteers. In order to optimize staffing resources, it is important to match the skills to the needed tasks. Someone will do a better job if they are good at the task or interested in doing the task. We have staff fill out a form which includes experiences, skills, what they like to do, what they do not like to do, and what they want to learn. We then use the form to assign tasks to the students. We use Asana to keep track of tasks and projects. ${ }^{17}$ Projects are assigned to all of the students. The project manager initially assigns the tasks to the other students. If a student is not able to complete the task, they are able to reassign the task. Depending on the urgency of the task, the student may keep the task and work on it the next time she or he is working. We use a Microsoft Outlook calendar to schedule workers. All staff have access to the calendar and can switch times with others. The calendar is useful in assigning tasks. 
Financial resources include the library's budget and donations. Physical resources include the physical library space and how it is used. The library's website can also be considered as space even though it is not physical. It is a virtual space which the distance students inhabit. Informational resources include physical books, periodicals, audio material, and video, as well as the online counterparts to these.

Optimizing resources means knowing your limitations. All four types of resources have their limits, especially for small libraries. Limitations to personnel resources include time. Staff have a limited amount of time. Tasks take a specific amount of time to complete. Sometimes tasks can take more time than is available. Staff also have limitations in expertise. It is important to know one's own strengths and weaknesses and those of the staff. Financial resources, or lack thereof, can also be a significant limitation.

I am learning to see my limitations. I want to do it all. If I start something new, I want to continue to do all the things I have been doing. This isn't always possible because of the limits of my library's resources. In The Practice of Adaptive Leadership, Ronald Heifetz, Alexander Grashow, and Martin Linsky talk about how adaptive leadership means that there will be losses. ${ }^{18}$

I am currently working on a strategic plan for our library so that I can more clearly state the library's vision for the next several years and its focus. This will help me know where to go and what to let go. We can then focus our resources on what is more important rather than what we have been doing or what we enjoy doing. What is our mission? How does it support the mission of the school? I have been thinking about elegant simplicity and the need to focus on assessment and evaluation so that I know that our actions and goals align with our mission and vision. Our focus should also be on our strengths. An analysis of resources in terms of our strengths is crucial to optimizing them.

As we work on our strategic plan, I need to constantly remind myself that if I add something, I will need to subtract something. I am learning to say, "no.” This is different from saying, "I can’t.” Rather, it is an acknowledgement of the truth of limitations: "If I do that, I will not be able to do something else. Right now, my priorities are elsewhere." The strategic plan will help me to articulate those priorities. 


\section{ACTING BOLDLY AT LANCASTER}

Not much has changed about Lancaster Theological Seminary over the past three years since the article in Theological Librarianship was published. It is still a small school and reported an FTE of 86 in the 2018-19 academic year. The library has approximately 430 current patrons, including students, faculty, staff, alumni, visiting students and faculty, and community members. We are averaging around 100 individuals logging into their library accounts each month. Total physical circulation (checkouts, renewals, and local use) spans from around 300 items per month when classes are not in session to over 800 items in our busiest months. We are nearing the end of a major weeding project and have removed approximately 60,000 items from our collection so far, bringing our current total number of items down to approximately 109,000. Our staff includes another full-time librarian, two part-time assistants, and up to two student workers.

The most notable way I have been able to lead my small library in acting boldly has been through our continued improvements to discovery and access of our collections and subscriptions, both print and electronic. Lancaster Seminary's library has become an early adopter of a few library technologies and we're now on the leading edge of developments to Koha, an open source integrated library system. Our small size was a major factor in how we were able to do this-an asset that I was able to leverage to bring much-needed improvements to our patrons.

Shortly after we migrated to Koha, EBSCO developed a plugin that would bring EBSCO Discovery Service (EDS) searches into the Koha interface using API. After trying another discovery service and since most of our database and electronic journal subscriptions are consolidated with EBSCO, I began asking about special pricing for our library. Partly because we wanted to adopt the newly developed plugin for Koha and also because we were of a smaller size, the pricing I received was within our reach and we were able to move forward as one of the first Koha libraries to implement the EDS API plugin.

After implementing that change, it became clear that we also needed to improve authentication pathways to our resources, particularly for patrons accessing electronic resources from off campus. I was able to innovate a way to provide direct URLs in patron accounts that 
would be accessible when a patron logged in, but this was cumbersome and problematic when a patron was attempting off-campus searches of EDS through our Koha interface. After a year of researching alternatives, I was approached by EBSCO to consider OpenAthens, an authentication platform developed by the UK company Eduserv. Our implementation of OpenAthens coincided with EBSCO's development of an OpenAthens plugin for Koha. Though the process was long and had many different phases, we were EBSCO's first OpenAthens customer in Pennsylvania and one of the earliest adopters of the OpenAthens plugin among Koha libraries. Our patrons can now search EDS and access our databases seamlessly once they have successfully logged in to their library account, with licensed access permissions tailored to their patron category and regardless of whether they are on campus or remote.

Facility with implementing these new technologies in the library gave me the confidence to agree to join an early adopter program for upgrades to Koha through our support company, ByWater Solutions. My staff and our users had shown a level of flexibility, understanding, and patience that is needed for early adoption. Being an early adopter for Koha upgrades has meant that our library is one of the first libraries partnered with ByWater to be migrated to the next stable release of Koha. This often means that there are a few bugs in the system that have not yet been identified. Early adopters are often tasked with finding and reporting these bugs so that the community can develop, test, and release patches. For open source software, this is an important community-driven process and it offers me a sense of fulfillment and purpose that our small library is helping to make a difference beyond our own context.

Our reputation as early adopters has led to an even deeper partnership that is presently having a direct impact on future developments of Koha. Earlier this year, our library was selected by the developers at ByWater to test and implement Elasticsearch, a new search engine technology that is being integrated into Koha. ${ }^{19}$ Elasticsearch is faster and more robust than Zebra, the default search engine for Koha. With it we can customize our mappings and set our own relevancy rankings, giving us more control over search results and reducing the number of irrelevant titles that appear higher in the results list. It will also eventually support browse functionality for bibliographic and authority 
records. Elasticsearch developments had reached a stall in the Koha community because not enough libraries were using it. When asked why our library was a good candidate for this opportunity, the developers answered that it was in part because of our size. We have enough diversity in our records to test a variety of search functions, yet not too many records that would take a long time to re-index when updates are made. We have enough staff and users to use and test the system, but not too many that would make collecting reports of bugs difficult or cumbersome. It was an equally attractive prospect for us because we receive the added benefit of being able to test and enjoy leadingedge technology and one-on-one support without added costs that usually come with enhancements and customizations.

As I reflect on the ways we've been able to capitalize on our small size to bring innovations to our library systems, I see that acting boldly is often dependent upon the librarian's strengths, interests, and personality. Yes, our library was the right size and in the right place at the right time to be able to find and act upon the opportunities to integrate EDS, OpenAthens, and Elasticsearch into our Koha installation. However, it was also the combination of my strengths in library systems and my interest in open source development that made our early adoption of these technologies successful. I used to think it was simply a matter of weighing risk over reward and analyzing the cost-benefit of various actions. What I am now realizing is that my own attitudes influence these equations. I believe there are many and various ways in which small libraries can take bold action and become trend-setters rather than trend-followers, but these will emerge influenced by our own personalities and attitudes as librarians and leaders of small libraries.

To expand on cultivating the habit of acting boldly, I propose that there are several attitudes that lend themselves to bold action. Curiosity is key. One must be ready to ask questions and explore in order to find opportunities to act boldly. Accompanying that is confidence and courage. Acting boldly requires a level of confidence to venture in a new direction and courage to face any obstacles or failures in the process. Persistence is also extremely important. Bold action rarely results in an immediate, resounding success. It often takes additional work, troubleshooting, and problem-solving. When too many obstacles arise, humility is necessary to learn from the experience, remain 
open to constructive criticism, and discern a new path forward.

There are also attitudes that present challenges to cultivating the habit of acting boldly. Perfectionism can be particularly crippling, as can rigidity, failure to recognize limits, and losing the connection to needs and available resources. Self-awareness is critically important to be able to recognize what attitudes and inclinations one might have that would interfere with or inhibit bold action. For me, this is a continual process of discernment and reflection.

\section{ENDNOTES}

1 Myka Kennedy Stephens, "The Future of the Small Theological Library,” Theological Librarianship 9, no. 1 (April 2016): 28 and 31, https://doi.org/10.31046/tl.v9i1.411.

2 Stephens, "The Future of the Small Theological Library," 28.

3 Stephens, "The Future of the Small Theological Library," 28.

4 Stephens, "The Future of the Small Theological Library," 30.

5 Stephens, "The Future of the Small Theological Library," 30.

6 Stephens, "The Future of the Small Theological Library," 29.

7 "Seminary Library Tutorials: General Research Tutorials," Reeves Library, Moravian College, accessed September 23, 2019, https://moravian.libguides.com/seminarytutorials.

8 Stephens, "The Future of the Small Theological Library," 31.

9 "Recommended Resources for Clergy and Alums: Congregational and Professional Resources," Reeves Library, Moravian College, accessed September 23, 2019, https://moravian.libguides.com/clergyandalums.

10 “Free Web Resources on Religion," Yale University Library, accessed September 23, 2019, https://guides.library.yale.edu/freeweb.

11 “STEP Bible," Tyndale House, accessed September 23, 2019, https://stepbible.org.

12 “Zotero: Your Personal Research Assistant," Corporation for Digital Scholarship, accessed September 23, 2019, https:// zotero.org.

13 Rebecca Z. Kuglitsch and Peggy Burge, "Beyond the First Year: Supporting Sophomores Through Information Literacy Outreach," College and Undergraduate Libraries 23, no. 1 (2016): 89. 
14 Kuglitsch and Burge, "Beyond the First Year," 89.

15 Stephens, "The Future of the Small Theological Library," 29.

16 "Framework for Information Literacy for Higher Education," Association of College \& Research Libraries, accessed September 23, 2019, http://www.ala.org/acrl/standards/ilframework.

17 “Asana," Asana, accessed September 23, 2019, https://asana.com.

18 Ronald Heifetz, Alexander Grashow, and Marty Linsky, The Practice of Adaptive Leadership: Tools and Tactics for Changing Your Organization and the World (Boston: Harvard Business School Publishing, 2009), 96.

19 Nick Clemens, “Kohacon 2019: Elasticsearch Update," ByWater Solutions, accessed September 23, 2019, https://bywatersolutions.com/news/kohacon-2019-elasticsearch-update. 